\title{
Sourgrass and fleabane are controlled by haloxyfop-p- methyl and cloransulam-methyl interaction and interval of application
}

\author{
Jéssica F. L. Leal ${ }^{a}$ (D), Junior Borella ${ }^{\text {a,b }}$ (D), Amanda dos S. Souza ${ }^{a}$ (D), Gabriella Francisco P. B. de Oliveira ${ }^{a}$ (D), \\ Ana Claudia Langaro ${ }^{a}$ (D), Camila F. de Pinho* (D) \\ a Federal Rural University of Rio de Janeiro, Seropédica, RJ, Brazil. ' Federal University of Rio Grande, Rio Grande, RS, Brazil.
}

Abstract: Background: Areas simultaneously infested with both glyphosate-resistant sourgrass (Digitaria insularis L.) and fleabane (Conyza spp.) are usual in Brazil. However, there are no effective management strategies to control both species concurrently.

Objective: The aim was to evaluate the interaction and interval of application of haloxyfop-P-methyl and cloransulam-methyl to effective control sourgrass (from 3 - to 4-tillers to flowering stages) and fleabane (12- to $15-\mathrm{cm}$ at the vegetative stage).

Methods: The experiment was conducted twice in a randomized complete blocks design with four biological replicates. The treatments were composed of sequential applications of haloxyfop-P-methyl (firstly applied) and cloransulam-methyl (secondly applied) and vice-versa. After the first application, the second one was applied in intervals of 3, 6 and 12 days. Haloxyfop-P-methyl and cloransulam-methyl were also applied in sequential (without interval), stand-alone applications of both herbicides and an untreated check.

Results: All treatments effectively controlled all fleabane plants. Haloxyfop-P-methyl applied $\geq 6$ days before cloransulam-methyl controlled $100 \%$ of 3 - to 4 -tillers sourgrass and $60 \%$ of flowering sourgrass.

Conclusions: Therefore, haloxyfop-P-methyl may be applied $\geq 6$ days before cloransulam-methyl in a sequential application structure to effectively control fleabane and sourgrass (3- to 4-tillers stage), when present concurrently.

Keywords: Antagonism; Conyza spp., Digitaria Insularis, Herbicide Interaction; Interval of Application

Journal Information:

ISSN - 2675-9462

Website: http://awsjournal.org

Journal of the Brazilian Weed

Science Society

How to cite: Leal JFL, Borella J, Souza AS, Oliveira GFPB, Langaro AC, Pinho

CF. Sourgrass and fleabane are controlled by haloxyfop-p-methyl and cloransulam-methyl interaction and interval of application. Adv Weed Sci. 2021;39:e21237936.

hittps://doi.org/10.51694/AdrWeedSci/2021;39:00010

Approved by:

Editor in Chief: Anderson Luis Nunes

Conflict of interest: The authors declare that they have no known competing for financial interests or personal relationships that could have appeared to influence the work reported in this paper

Received: May 12, 2020

Approved: February 18, 2021

* Corresponding author: <camilafepi@hotmail.com>

\section{(c) (7)}

This is an open-access article distributed under the terms of the Creative Commons Attribution License, which permits unrestricted use, distribution, and reproduction in any medium, provided that the original author and source are credited.

Copyright: 2021

\section{Introduction}

Digitaria insularis L. (sourgrass.) and Conyza spp. L. (fleabane) are considered the main weeds in areas of grain production in Brazil, causing serious losses due to competition with the crops of interest for essential resources (Blainski et al., 2015; Hao et al., 2009). The problem is worsened when both species are resistant to glyphosate and present in the same cropping area, which difficult the management and increases the costs to control them.

The control of both species concurrently requires the combined use of herbicides with different modes of action. The control of these species can be more effective by applying acetyl-coenzyme carboxylase (ACCase)-inhibiting herbicides to control glyphosate-resistant sourgrass (Barroso et al., 2014; Leal et al., 2020; Melo et al., 2012), and acetolactate synthase (ALS)-inhibiting herbicides to control fleabane (Blainski et al., 2015; Bressanin et al., 2014), mainly when there are weed resistance cases to glyphosate in glyphosate-resistant soybean (Glycine max (L.) Merr) areas. However, not all herbicides can be used in tank-mix combinations, due to incompatibility or antagonism between herbicides (Colby, 1967; Zhang et al., 1995). The effects of herbicide tank-mix application or sequential application depend on plant species, phenological stage and environmental conditions (Damalas et al., 2004).

Antagonistic effects often occur when herbicides used for grass control are applied at the same time or after the application of herbicides used for dicotyledonous control (Leal et al., 2020; Ottis et al., 2005; Rustom et al., 2018; Webster et al., 2019; Zhang et al., 1995). About $80 \%$ of antagonistic interactions occur in species of the family Poaceae (grasses) (Damalas et al., 2004; Zhang et al., 1995). Glyphosate previously provided excellent control of fleabane and sourgrass; however, with the evolution of glyphosate-resistant weeds in Brazil, alternative herbicides must be identified to provide effective control of these weeds in soybean. As reported by our group, fleabane and sourgrass can be controlled with herbicides by applying haloxyfop $>6 \mathrm{~d}$ before 2,4-D (Leal et al., 2020). However, there are few options to control weeds, when present concurrently in the post-emergence soybean system.

ALS-inhibiting herbicides are reported to antagonize ACCase-inhibiting herbicides, causing a decrease in grass control (Bhullar et al., 2016; Myers and Coble, 1992; Ottis 
et al., 2005; Rustom et al., 2018). Negative interactions between herbicides in tank-mix or sequential applications can be attributed to changes in the amount of herbicide that reaches the site of action within plants through changes in its absorption, translocation or metabolism due to the presence of other herbicide (Barnes and Oliver, 2004). The effect of herbicide combination can be maximized or minimized depending on the interval between applications that are adopted in the management system (Burke et al., 2002; Leal et al., 2020).

Haloxyfop-P-methyl and cloransulam are the main post-emergence herbicides recommended controlling sourgrass and fleabane, respectively, especially in glyphosate-tolerant soybean systems. However, there is little technical information about the interval and sequential herbicides application and how this may impair weed control when they are present concurrently in the crop system. This work aimed to evaluate the use of different sequences and intervals of application of the herbicides haloxyfop-P-methyl and cloransulam-methyl to effectively control both sourgrass (from 3- to 4-tillers to flowering stages) and fleabane (at 12- to 15-cm tall).

\section{Materials and methods}

\subsection{Plant materials and growth conditions}

Digitaria insularis L. (sourgrass.) and Conyza spp. L. (fleabane), collected in 2015 from a soybean field in Mogi Mirim City, were used to carry out an experiment (performed twice). Plants previously germinated from seeds in a 1-L polyethylene pot with Planosol soil (Santos et al., 2013) filled with sandy loam soil ( $18 \%$ clay, $5 \%$ silt, $77 \%$ sand), were transplanted to $1 \mathrm{~L}$ pot (one plant per pot), containing soil as substrate. According to soybean crop management (Freire, 2013), the soil was amended with $1.5 \mathrm{t} \mathrm{ha}^{-1}$ dolomitic calcareous (relative power of total neutralization $=80 \%$ ) and fertilized with $80 \mathrm{~kg} \mathrm{ha}^{-1}$ of $\mathrm{P}_{2} \mathrm{O}_{5}$ and $60 \mathrm{~kg} \mathrm{ha}^{-1}$ of $\mathrm{K}_{2} \mathrm{O}$. Afterward, the soil presented the chemical characteristics: $\mathrm{pH}$ (water) $=5.8$; organic matter $=0.25 \mathrm{dag} \mathrm{kg}^{-1}$ (0.25\%); $\mathrm{P}\left(37.2 \mathrm{mg} \mathrm{dm}{ }^{-3}\right)$ and $\mathrm{K}(77 \mathrm{mg}$ $\left.\mathrm{dm}^{-3}\right)$. Besides the amendment, the soil was fertilized with nitrogen, phosphorus, and potassium (NPK, 5-20-20), once per week and irrigated daily at field capacity.

The experiment was conducted with fleabane at 12- to 15-cm tall and with sourgrass at 3- to 4- tillers and flowering stages, respectively, arranged in a randomized complete block design with four biological replicates and conducted twice temporally (two runs). The treatments consisted of the application of two herbicides in different order of application: haloxyfop-P-methyl (62 g ea. ha ${ }^{-1}$ ) (Verdict ${ }^{\circ}, 120$ g e.a. $\mathrm{L}^{-1}, \mathrm{EC}$, Corteva Agriscience) and cloransulam-methyl $\left(40\right.$ g ai. ha $\left.{ }^{-1}\right)$ (Pacto ${ }^{\circ}, 840$ g a.i. . L ${ }^{-1}$, WG, Corteva Agriscience) and sequential applications made at 3, 6 and 12 days after the first application. Besides, haloxyfop-P-methyl and cloransulam-methyl applied sequentially, stand-alone and an untreated check treatment were also included (Table 1).
Table 1 - Treatment structure for Digitorio insuloris

(sourgrass) and Conyza spp (fleabane) control evaluation of

greenhouse experiments.

Application

sequence

\begin{tabular}{|c|c|c|c|}
\hline Herbicide programª & $1^{\text {st }}$ & $2^{\text {nd }}$ & $\begin{array}{l}\text { Application } \\
\text { interval } \\
\text { (Days) }\end{array}$ \\
\hline
\end{tabular}

\begin{tabular}{|c|c|c|c|}
\hline Untreated & Untreated & - & - \\
\hline Cloransulam & Cloransulam & - & - \\
\hline Haloxyfop & Haloxyfop & - & - \\
\hline Halox+cloran ${ }^{1}$ & $\begin{array}{l}\text { Haloxyfop+- } \\
\text { Cloransulam }\end{array}$ & - & - \\
\hline Cloran / halox (3)² & Cloransulam & Haloxyfop & 3 \\
\hline Cloran / halox (6) 2 & Cloransulam & Haloxyfop & 6 \\
\hline Cloran / halox (12)² & Cloransulam & Haloxyfop & 12 \\
\hline Halox / cloran (3) & Haloxyfop & Cloransulam & 3 \\
\hline Halox / cloran $(6)^{2}$ & Haloxyfop & Cloransulam & 6 \\
\hline Halox / cloran (12) & Haloxyfop & Cloransulam & 12 \\
\hline
\end{tabular}

abbreviations: ${ }^{1}$ Sequential haloxyfop-P-methyl and cloransulam herbicides; ${ }^{2}$ interval between the first and second application (3, 6 and 12 days).

When plants reached the above-mentioned growth stage, the plants were sprayed using a $\mathrm{CO}_{2}$-pressurized backpack sprayer equipped with four TeeJet XR110015 flat-fan nozzles (TeeJet Technologies), which delivered $150 \mathrm{~L} \mathrm{ha}^{-1}$ of spray solution at $280 \mathrm{kPa}$ and a ground speed of $4.53 \mathrm{~km} \mathrm{hr}^{-1}$.

\subsection{Visual control analysis}

Weed control was performed by visual assessments using a scale of 0 to $100 \%$ [where $0 \%$ represents the absence of symptoms and $100 \%$ represents the death of the plant (Frans et al., 1986). The analysis was performed at 14 and 35 days after the last application (DALA) for sourgrass and at 7 and 35 DALA for fleabane (Leal et al., 2020).

\subsection{Analysis of chlorophyll a fluorescence}

Measurements of $\mathrm{Chl}$ a fluorescence transient were taken in intact young leaves with a fully expanded first leaf of sourgrass plants at 3- to 4- tiller in two periods (14 and 35 DALA), in dark-adapted (at least $20 \mathrm{~min}$ in specially provided clips) leaves attached to the plant by using a Handy-PEA fluorimeter (Plant Efficiency Analyzer, Hansatech Instruments Ltd, UK). The fluorescence was induced by one saturating red-light flash (peak at 650 $\mathrm{nm})$ with $3.000 \mu \mathrm{mol}$ photons $\mathrm{m}^{-2} \mathrm{~s}^{-1}$, to measure the polyphasic fluorescence rise (OJIP) during the first second of illumination ( $10 \mu \mathrm{s}$ to $1 \mathrm{~s})$ as described in Strasser et al. (2004). Among the parameters selected by the highlighted JIP-test: $\varphi$ Ro - Quantum yield for reduction of end electron acceptors at the PSI acceptor side (RE); $\varphi$ Eo - Quantum yield for electron transport (ET); $\varphi$ Do - Maximum quantum yield of non-photochemical de-excitation; $\mathrm{PI}_{\mathrm{ABS}}$ - Performance index (potential) for energy conservation from exciton to the reduction of 
intersystem electron acceptors; $\mathrm{PI}_{\text {total }}$ - Performance index (potential) for energy conservation from exciton to the reduction of PSI end acceptors. $\mathrm{DI}_{0} / \mathrm{RC}$ - Dissipation of an active RC; ABS/RC- a measure of the apparent size of the antenna system; $\mathrm{TR}_{0} / \mathrm{RC}$ - Maximum trapping rate per $\mathrm{RC}$.

The OJIP-steps (relative variable fluorescence) were analyzed using the JIP-test parameters [see Strasser et al. (2004) and Tsimilli-Michael and Strasser (2008)]. Normalizations and subtractions of the JIP-test were employed to show events reflected in the OJ-, OI-, and IP-phases according to Yusuf et al. (2010).

\subsection{Dry mass analysis}

Shoot and roots of plants (at 35 DALA) were carefully separated and placed in a paper bag. For drying, they were placed in an oven $\left(60 \pm 5^{\circ} \mathrm{C}\right)$ with forced air circulation. When plants reached constant mass $(\sim 72 \mathrm{~h})$, they were weighed to determine the shoot dry mass (SDM) and root dry mass (RDM).

\subsection{Statistical analysis}

The data of both experiments were checked for normality (Shapiro-Wilk) and homogeneity (Bartlett) of variance and then analysis of variance (ANOVA) was performed considering run as a fixed factor. Since no significant effect ( $p>0.05$ ) was verified, data from both experiments were combined. Data were analyzed using the GLM procedure to evaluate the differences between treatments. When $F$ was significant, the treatment means were separated at $\mathrm{p} \leq$ 0.05 and adjusted using Fisher's Protected LSD. Statistical analyses were performed using the SAS 9.0 statistical software program (SAS Institute Inc., Cary, $\mathrm{NC}$ ).

\section{Results and discussion}

Interaction of change to run-by-treatment was not significant $(p>0.05)$ for visual weed control, SDM and RDM. Therefore, data were pooled across runs. Haloxyfop-P-methyl and cloransulam-methyl applied in sequential, regardless of application order and interval, and cloransulam-methyl alone provided $100 \%$ control of fleabane (Table 2). This result confirms the sensitivity of fleabane to inhibitory herbicides of ALS mode of action (Blainski et al., 2015; Bressanin et al., 2014) and the absence of antagonism in the association between the herbicides haloxyfop-P-methyl and cloransulam-methyl to control fleabane.

As expected, haloxyfop-p-methyl alone did not affect fleabane. Haloxyfop-P-methyl alone did not control fleabane, since ACCase-inhibiting herbicides have no effects in dicotyledonous (Table 2), due to the presence of the herbicide-tolerant prokaryotic form of ACCase enzyme, compared to grasses which have the herbicide-sensitive eukaryotic form (Sasaki and Nagano, 2004).
Table 2 - Conyzo spp (fleabane) control at 7 and 35 days after last application (DALA), shoot dry mass (SDM) and root dry mass (RDM) of fleabane plants at $12 \mathrm{~cm}$ stage subjected to the sequential use of the haloxyfop-P-methyl and cloransulam, and cloransulam and haloxyfop-P-methyl at 3, 6 and 12-day intervals between applications.

\begin{tabular}{|c|c|c|c|c|}
\hline \multirow[t]{2}{*}{ Treatments ${ }^{a}$} & \multicolumn{2}{|c|}{----Control (\%)b----- } & \multicolumn{2}{|c|}{--- Dry mass (g) } \\
\hline & 7DALA & 35DALA & SDM & RDM \\
\hline Untreated & - & - & $1.47 b$ & $2.72 b$ \\
\hline Cloransulam & $47 \mathrm{bc}$ & $100 \mathrm{a}$ & $\mathrm{Oc}$ & $\mathrm{Oc}$ \\
\hline Haloxyfop & $\mathrm{Oe}$ & $\mathrm{Ob}$ & 1.72 a & 3.15 a \\
\hline Halox+cloran ${ }^{1}$ & 68 a & $100 \mathrm{a}$ & $\mathrm{Oc}$ & $\mathrm{Oc}$ \\
\hline Cloran / halox (3)² & 65 a & 100 a & $\mathrm{Oc}$ & $\mathrm{Oc}$ \\
\hline Cloran / halox (6) 2 & 70 a & $100 \mathrm{a}$ & $\mathrm{Oc}$ & $\mathrm{Oc}$ \\
\hline Cloran / halox (12) ${ }^{2}$ & $56 a b$ & 100 a & $\mathrm{Oc}$ & $\mathrm{Oc}$ \\
\hline Halox / cloran (3)² & $35 \mathrm{~cd}$ & 100 a & $\mathrm{Oc}$ & $\mathrm{Oc}$ \\
\hline Halox / cloran $(6)^{2}$ & 65 a & 100 a & $\mathrm{Oc}$ & $\mathrm{Oc}$ \\
\hline Halox / cloran (12)² & $25 d$ & $100 \mathrm{a}$ & $\mathrm{Oc}$ & $\mathrm{Oc}$ \\
\hline LSD & 14.47 & 0.58 & 0.1784 & 0.284 \\
\hline
\end{tabular}

${ }^{a}$ Abbreviations: ${ }^{1}$ Sequential haloxyfop-P-methyl and cloransulam herbicides; ${ }^{2}$ interval between the first and second application ( 3,6 and 12 days). bVisual control estimates of sourgrass were made 7 and 35 after last application DALA.

"Dry mass- SDM, shoot dry mass (g plant ${ }^{-1}$ ) and RDM, root dry mass (g plant ${ }^{-1}$ ) were made 35 after last application DALA. Values are given as means $(n=8)$.

Within a column, means followed by the same letter are not significantly different at $p<0.05$, using the Fisher's Protected LSD.

Haloxyfop-P-methyl applied $\geq 6$ days before cloransulam-methyl controlled sourgrass at 3 - to 4-tillers and flowering stage equivalently to haloxyfop-P-methyl alone (Table 3 and 4). At 3- to 4-tiller these treatments controlled $\geq 60 \%$ sourgrass at 14 DALA and $100 \%$ at 35 DALA, regarding the reduction of $100 \%$ in dry mass when compared to untreated plants (Table 3). All other treatments at 35 DALA controlled 3- to 4-tiller sourgrass about 35 to $56 \%$ (Table 3). Haloxyfop-P-methyl applied $\geq 6$ days before cloransulam-methyl at the flowering stage controlled $\geq$ $35 \%$ at 14 DALA and $60 \%$ at 35 DALA, equivalently to haloxyfop-P-methyl alone. Furthermore, at 35 DALA, other treatments controlled sourgrass at the flowering stage in about $\leq 40 \%$ (Table 4 ).

Chl $a$ fluorescence analysis presented an increase in the relative variable fluorescence $\left(\mathrm{W}_{\mathrm{t}}\right.$ ) (Figure 1a) and increase in the flux of energy dissipated (heat) per active reaction center $\left(\mathrm{DI}_{0} / \mathrm{RC}\right)$ and quantum yield of energy dissipation $\left(\phi_{\mathrm{Do}}\right)$ in sourgrass plants at 3- to 4- tillers stage, treated with haloxyfop-P-methyl at 14 DALA (Figure 2a). There was an increase in the sequence of events from exciton trapping by PSII up to plastoquinone (PQ) reduction, shown in the OI-phase (Figure 1c) and the parameter $\mathrm{TR}_{0} / \mathrm{RC}$ [energy trapping flux per $\mathrm{RC}$ which can lead a reduction of quinone $\left.\left(Q_{A}\right)\right]$ (Figure 2a). However, there was a decline of the electron transfer from $\mathrm{PQH}_{2}$ to the end electron acceptor of the PSI acceptor side, as highlighted in the IP-phase (Figure 1e). Also, decreases occurred in $\phi_{\text {Ео }}$ (quantum yield for electron 
Table 3 - Digitorio insularis (sourgrass) control at 14 and 35 days after last application (DALA), shoot dry mass (SDM) and root dry mass (RDM) of sourgrass plants at the stage of 3-4 tillers subjected to the sequential use of the haloxyfop-P-methyl and cloransulam, and cloransulam and haloxyfop-P-methyl at 3, 6 and 12-day intervals between applications.

3-4 tillers stage

\begin{tabular}{|c|c|c|c|c|}
\hline \multirow[t]{2}{*}{ Treatments ${ }^{a}$} & \multicolumn{2}{|c|}{----Control (\%)b---- } & \multicolumn{2}{|c|}{---- Dry mass $(g)^{c}$} \\
\hline & 14DALA & 35DALA & SDM & RDM \\
\hline Untreated & - & - & $4.1 \mathrm{a}$ & 1.14 a \\
\hline Cloransulam & $O f$ & Od & $4.31 a$ & $1.09 a b$ \\
\hline Haloxyfop & $60 \mathrm{~b}$ & 100 a & $\mathrm{Oe}$ & Od \\
\hline Halox+cloran ${ }^{1}$ & $40 d$ & $55 b$ & $1.23 d$ & $0.59 \mathrm{c}$ \\
\hline Cloran / halox (3)² & $20 \mathrm{e}$ & $35 c$ & $3 b$ & $0.99 b$ \\
\hline Cloran / halox (6) ${ }^{2}$ & $25 \mathrm{e}$ & $36 \mathrm{c}$ & $2.17 c$ & $0.6 c$ \\
\hline Cloran / halox (12) ${ }^{2}$ & $24 \mathrm{e}$ & $39 c$ & $1.88 \mathrm{c}$ & $0.56 \mathrm{c}$ \\
\hline Halox / cloran (3)² & $50 \mathrm{c}$ & $56 b$ & $2.13 c$ & $0.56 \mathrm{c}$ \\
\hline Halox / cloran $(6)^{2}$ & 70 a & 100 a & $\mathrm{Oe}$ & Od \\
\hline Halox / cloran (12)2 & $71 a$ & $100 a$ & $\mathrm{Oe}$ & Od \\
\hline LSD & 7.57 & 7.13 & 0.5422 & 0.14 \\
\hline
\end{tabular}

Abbreviations: 'Sequential haloxyfop-P-metyl and cloransulam herbicides; 2interval between the first and second application (3, 6 and 12 days). Visual control estimates of sourgrass were made 14 and 35 after last application DALA.

'Dry mass- SDM, shoot dry mass (g plant ${ }^{-1}$ ) and RDM, root dry mass (g plant ${ }^{-1}$ ) were made 35 after last application DALA.

Values are given as means $(n=8)$.

Within a column, means followed by the same letter are not significantly different at $p<0.05$, using the Fisher's Protected LSD.

Table 4 - Digitaria insularis (sourgrass) control at 14 and 35 days after last application (DALA), shoot dry mass (SDM) and root dry mass (RDM) of sourgrass plants at flowering subjected to the sequential use of the haloxyfop-P-methyl and cloransulam, and cloransulam and haloxyfop-P-methyl at 3, 6 and 12-day intervals between applications.

Flowering stage

\begin{tabular}{|c|c|c|c|c|}
\hline \multirow{2}{*}{ Treatments $^{a}$} & \multicolumn{2}{|c|}{----Control (\%)b---- } & \multicolumn{2}{|c|}{----Dry mass (g)c---- } \\
\hline & 14DALA & 35DALA & SDM & RDM \\
\hline Untreated & - & - & $6.41 c$ & $2.5 b$ \\
\hline Cloransulam & $\mathrm{Oe}$ & $\mathrm{Oe}$ & $5.79 \mathrm{~cd}$ & $2.02 \mathrm{c}$ \\
\hline Haloxyfop & $41 a$ & $61 a$ & 4.14 ef & $1.82 \mathrm{c}$ \\
\hline Halox+cloransul ${ }^{1}$ & $11 d$ & $21 d$ & 10.7 a & $2.78 b$ \\
\hline Clorans / halox (3)² & $8 d$ & $30 \mathrm{c}$ & $8.52 \mathrm{~b}$ & 3.75 a \\
\hline Clorans / halox (6) ${ }^{2}$ & $8 d$ & 35 bc & $4.8 \mathrm{de}$ & $2.47 b$ \\
\hline Clorans / halox (12) & $8 d$ & $40 \mathrm{~b}$ & $4.74 \mathrm{de}$ & $1.96 \mathrm{c}$ \\
\hline Halox / clorans (3)² & $25 c$ & 35 bc & 4.07 ef & $1.62 \mathrm{~cd}$ \\
\hline Halox / clorans $(6)^{2}$ & $36 \mathrm{~b}$ & 63 a & 3.43 ef & $1.37 d$ \\
\hline Halox / clorans (12) & $35 b$ & 63 a & $3.24 f$ & $1.79 \mathrm{c}$ \\
\hline LSD & 3.66 & 6.93 & 1.49 & 0.41 \\
\hline
\end{tabular}

${ }^{2}$ Abbreviations: ${ }^{1 S e q u e n t i a l ~ h a l o x y f o p-P-m e t h y l ~ a n d ~ c l o r a n s u l a m ~ h e r b i c i-~}$ des; ${ }^{2}$ interval between the first and second application (3, 6 and 12 days). bVisual control estimates of sourgrass were made 14 and 35 after last application DALA.

'Dry mass- SDM, shoot dry mass (g plant ${ }^{-1}$ ) and RDM, root dry mass (g plant ${ }^{-1}$ ) were made 35 after last application DALA

Values are given as means $(n=8)$.

Within a column, means followed by the same letter are not significantly different at $p<0.05$, using the Fisher's Protected LSD. transport moves further than $\mathrm{Q}_{\mathrm{A}}{ }^{-}$) in about $40 \%$ and $\phi_{\mathrm{Ro}}$ (quantum yield for reduction of end electron acceptors at the PSI acceptor side) in about 20\% (Figure 2a), besides a decline in $70 \%$ the photosynthetic performance index $\left[\left(\mathrm{PI}_{\text {total }}\right)\right.$ performance index for energy conservation from exciton to the reduction of PSI end acceptor] (Figure 2a). Sourgrass plants increased about $40 \%$ of the parameter ABS/RC (a measure of the apparent antenna size of an active PSII) with haloxyfop-P-methyl treatment (Figure 2a).

When haloxyfop-P-methyl was applied 6 and 12 days before cloransulam-methyl, there was an increase in the photosynthetic performance by more than 80 and $15 \%$, respectively, at 14 DALA (Figure 2a). However, it is noteworthy that the interval of 6 days between applications induced dissipation of energy as non-photochemical
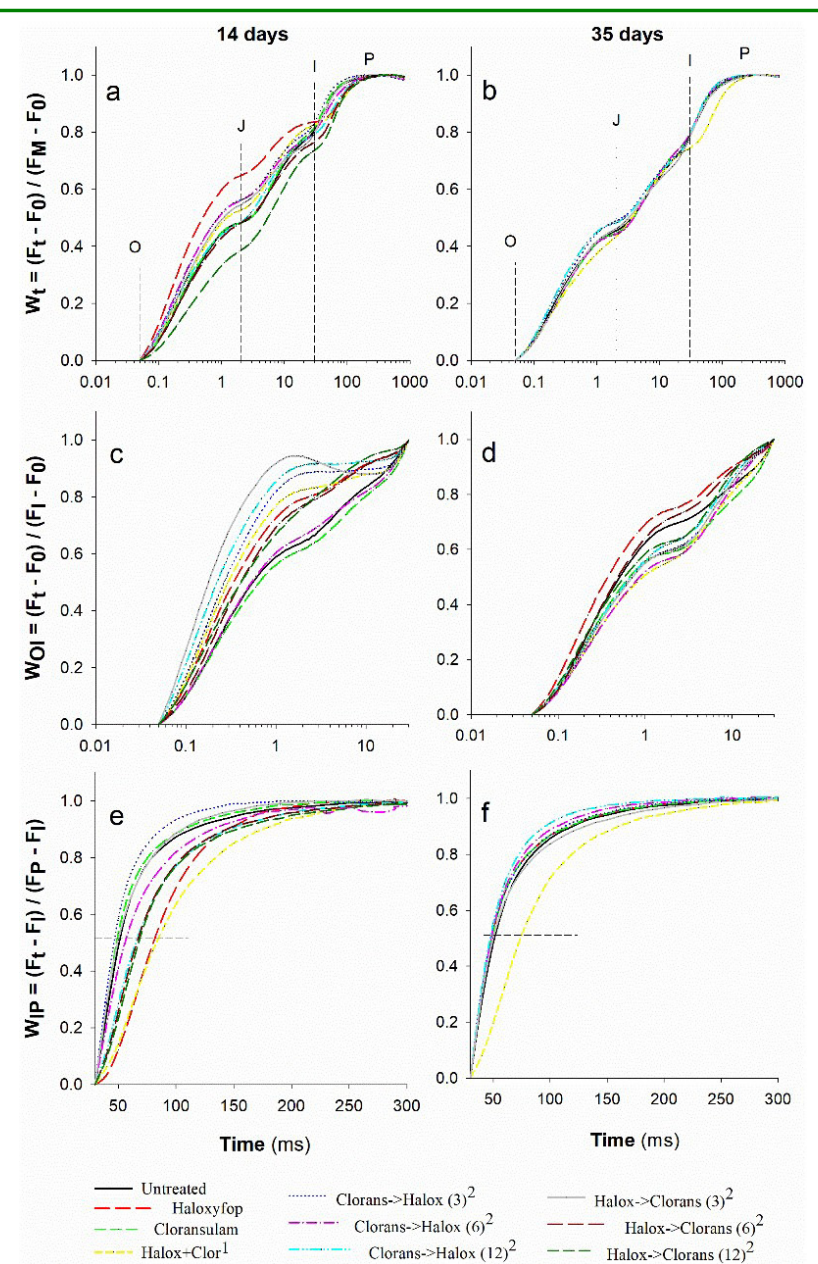

Abbreviations: ${ }^{1}$ Sequential haloxyfop and cloransulam herbicides;

${ }^{2}$ interval between the first and second application (3, 6 and 12 days).

Figure 1 - Chl a fluorescence transient of dark-adapted leaves for haloxyfop-P-methyl and cloransulam treatments applied at different intervals to control sourgrass at 3-4 tillers stages. Data correspond to the relative variable fluorescence between the steps $O$ and $P\left(W_{t}\right)$ ( $A$ and $B$ ); between the steps $O$ and I ( $\left.W_{0}\right)$ ( $C$ and $D$ ) and between the steps I and $P\left(W_{1 P}\right)(E$ and $F$ ) on a logarithmic time scale at 14DALA and 35 DALA. ms = milliseconds. $(n=8)$. 
quenching (heat and fluorescence) in about 20\% ( $\mathrm{DI}_{0} / \mathrm{RC}$ and $\phi_{D_{\mathrm{D}}}$ ) (Figure 2a). On the other hand, cloransulam-methyl showed no effect on sourgrass plants. Other treatments showed a reduction in performance indexes and an increase in energy dissipation as heat. Besides, there was an increase in the excitation captured by the RC (reaction center) until the reduction of $\mathrm{PQ}$ (OI-phase) (Figure1c) and a decrease in the electron transfer from $P Q$ to the final electron acceptor of the PSI as highlighted in the IP-phase (Figure 1d).

At 35 DALA, sourgrass plants (3- to 4-tillers) died when treated with haloxyfop-P-methyl applied 6 and 12 days before cloransulam-methyl and haloxyfop-P-methyl alone. The sequential haloxyfop-P-methyl and cloransulam-methyl applied without an interval of application induced an increase in the electron transfer from $P Q$ to the final electron acceptor of the PSI as highlighted in the IP-phase (Figure 1f), and declined photosynthetic performance by $20 \%$ while increased energy dissipation as heat in about $40 \%$ in sourgrass plants (Figure $2 \mathrm{~b}$ ). Other treatments did not affect the photosynthetic process (Figure 1 and 2). The decrease in the photosynthetic process may induce a reduction in dry mass, even if the stress was not enough to kill the plant.

The ACCase-inhibiting herbicides, such as haloxyfop-Pmethyl affect photosynthesis by inhibiting the fatty acid biosynthesis (Dayan and Zaccaro, 2012). Lipids are essential components of photosynthetic electron transport chain (chloroplast membrane) and phytol chain of chlorophylls. Decreases in lipid production affect the stability of photosynthesis which increases chlorophyll fluorescence (Dayan and Zaccaro, 2012). Fluorescence is a potential stress indicator that can be indicative of physiological disturbances before the appearance of visible symptoms of stress. This effect was observed in sourgrass by an increase in the relative variable fluorescence $\left(\mathrm{W}_{\mathrm{t}}\right.$; Figure $\left.1 \mathrm{a}\right)$, energy dissipation as heat $\left(\mathrm{DI}_{0} / \mathrm{RC}\right.$ and $\left.\phi_{\mathrm{Do}_{\mathrm{o}}}\right)$, and the decline in $70 \%$ in the photosynthetic performance $\left(\mathrm{PI}_{\text {abs }}\right.$ and $\mathrm{PI}_{\text {total }}$, when plants were treated with haloxyfop-P-methyl at 3- to 4-tillers stage at 14 DALA (Figure 2a). The decrease in the performance indexes indicates the loss of photochemical efficiency in plants (Thach et al., 2007). At 35 DALA, sourgrass plants did not withstand the stress induced by haloxyfop-P-methyl and died, showing the sensitivity of these plants to this herbicide.

On the other hand, as sourgrass plants are tolerant to cloransulam-methyl, the effects of this herbicide on the chlorophyll $a$ fluorescence are not observed in any of the evaluations (Figure 1 and 2), what may explain the biomass stabilization of treated plants when compared to the control.

Sourgrass plants that received cloransulam before haloxyfop-P-methyl, regardless of the application interval, as well as plants that received the treatment haloxyfop interval 3 days cloransulam, were not effectively controlled. Antagonistic effects between ACCase- and ALS-inhibiting herbicides were reported in italian ryegrass (Lolium perenne
L. ssp. multiflorum (Lam.) Husnot), goosegrass (Eleusine indica (L.) Gaertn), Sprangletop (Leptochloa chinensis (L.) Nees) and rice (Oryza sativa L.) (Bhullar et al., 2016; Burke et al., 2002, 2003).

The antagonistic effect between inhibitors of ACCase and ALS depends on the plant species and herbicides used

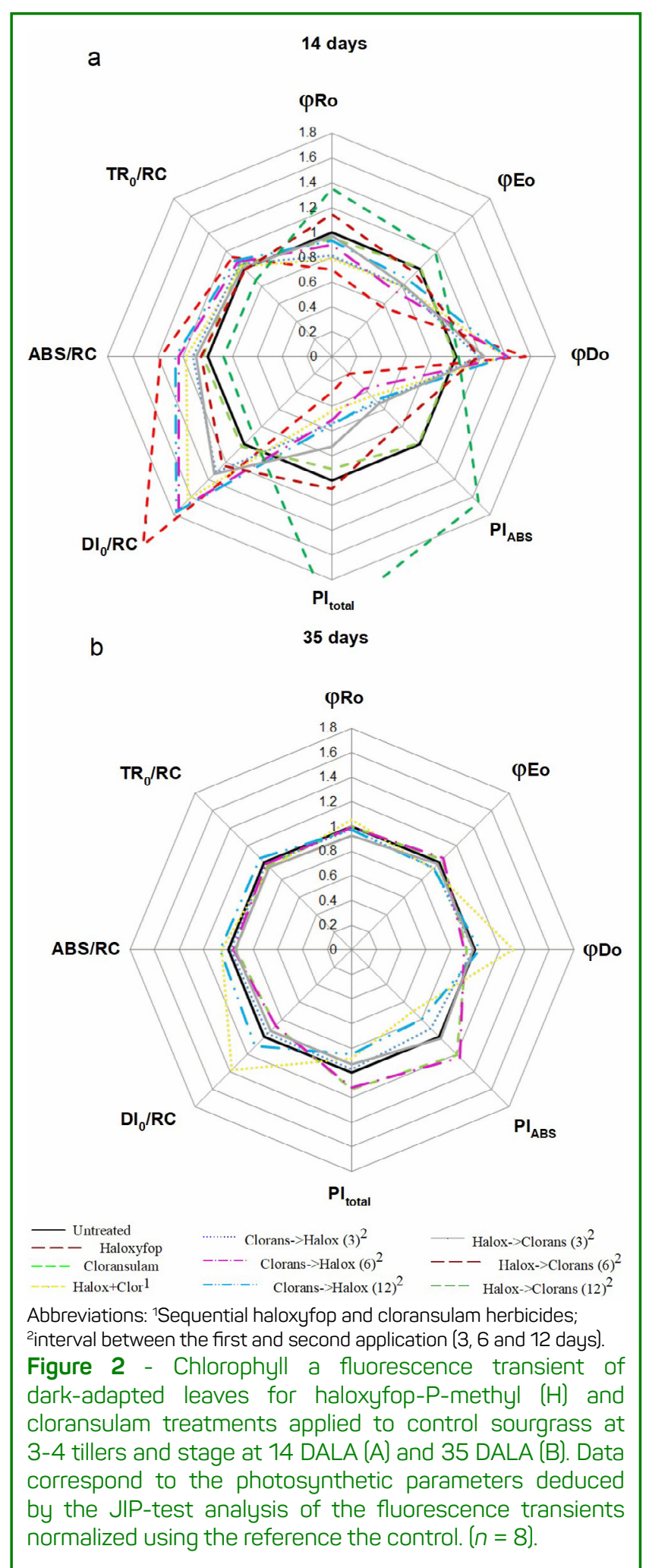


(Vieira Junior et al., 2015) and are often correlated with reduced absorption, reduced translocation of graminicides (Barnes and Oliver, 2004) and alteration in photosynthesis (Burke et al., 2003).

Reduction of photosynthetic performance in sourgrass of plants at 3- to 4-tillers was observed in treatments with unsatisfactory control, suggesting that cloransulam influences negatively photosynthesis of sourgrass when associated with haloxyfop-P-methyl. Several reports have reported that photosynthetic metabolism is impaired when herbicides are applied and it can be detected through chlorophyll a fluorescence (Dayan and Zaccaro, 2012), such as the application herbicides from imidazolinone group on rice plants (Sousa et al., 2014). Burke et al. (2003), suggest that the antagonism of clethodim by imazapic may be caused by imazapic reducing the photosynthetic rate of Eleusine indica and therefore the sensitivity of ACCase to clethodim. ACCase is located within the chloroplasts and on active meristematic tissues. Plants in fast-growing stages have a higher demand for cell membrane constituents, thus the ACCase-inhibiting herbicides are more active and efficient (Kukorelli et al., 2013). Therefore, the reduction of plant growth and photosynthesis caused by ALS inhibition would reduce plant demand for lipid biosynthesis by ACCase, thus reducing the efficacy of ACCase-inhibiting herbicides (Burke et al., 2003). The data showed that reduction in both photosynthetic performance and dry mass of sourgrass was due to cloransulam applied before haloxyfop-P-methyl, independent of the interval of application, haloxyfop-Pmethyl applied 3 days before cloransulam and the sequential of herbicides applied at the same day.

Haloxyfop-P-methyl applied $\geq 6$ days before cloransulam controlled sourgrass. The order and interval of application of haloxyfop-P-methyl and cloransulam are crucial to effective control sourgrass. The distribution of 7 days between graminicides and latifolicides (in this order) did not cause an anomaly in the control of broadleaf signalgrass (Urochloa platyphylla (Munro ex C. Wright) R.D. Webster), fall panicum (Panicum dichotomiflorum Michx), goosegrass (Eleusine indica) and crabgrass (Digitaria sanguinalis (L.) Scop) (Burke et al., 2002). As here reported, haloxyfop-P- methyl, when applied $\geq 6$ days before cloransulam, did not show a difference between the plants that received haloxyfop-P-methyl alone in the control of sourgrass.

At the flowering stage, no control of sourgrass was observed and this may be linked to the stage of plant development. Studies show that perennial plants have their control reduced (Zobiole et al., 2016). This is due to the increase in dry mass accumulation, clump formation, tissue lignification and the accumulation of starch in the rhizome that may hinder the translocation of herbicides (Gemelli et al., 2013; Machado et al., 2008). Therefore, the knowledge of the phenological stage of weeds is crucial for efficient control. Furthermore, haloxyfop-P-methyl should be applied at least 6 days before cloransulam in a sequential treatment regime to effectively control sourgrass. On the other hand, the control of fleabane does not depend on the application interval and sequence of cloransulam and haloxyfop-P-methyl.

\section{Conclusion}

Haloxyfop-P-methyl should be applied at least 6 days before cloransulam-methyl in a sequential application to control fleabane and sourgrass glyphosate-resistant when concurrently present. However, it is noteworthy to follow the recommendation of the phenological stage of the 3- to 4- tillers for sourgrass plants to effective control.

\section{Author' contributions}

All authors contributed for drafting and revising the manuscript. CFP, and JFLL: conception and design of the experiment. JFLL, JB, ASS, GFPBO, and ACL: data acquisition. JFLL, JB, and CFP: data analysis.

\section{Acknowledgments}

This study was financed in part by the Coordenação de Aperfeiçoamento de Pessoal de Nivel Superior-Brazil (Capes) - Finance Code 001 and Fundação Carlos Chagas Filho de Amparo à Pesquisa do Estado do Rio de Janeiro (Faperj).

\section{References}

Barnes JW, Oliver LR. Cloransulam antagonizes annual grass control with aryloxyphenoxypropionate graminicides but not cyclohexanediones. Weed Technol. 2004;18(3):763-72. Available from: https://doi.org/10.1614/WT-03-181R

Barroso AAM, Albrecht AJP, Reis FC, Filho RV. [Accase and glyphosate diferent formulations herbicides association interactions on sourgrass control]. Planta Daninha. 2014;32(3):619-27. Portuguese. Available from: https://doi.org/10.1590/S0100-83582014000300018

Bhullar MS, Kumar S, Kaur S, Kaur T, Singh J, Yadav R et al. Management of complex weed flora in dry-seeded rice. Crop Prot. 2016;83:20-6. Available from: https://doi.org/10.1016/j.cropro.2016.01.012
Blainski E, Maciel CDG, Zobiole LHS, Rubin RS, SilvaAAP, Karpinski RAKet al. [Cloransulam-methyl efficiency in postemergence control of Conyzo bonoriensis in RR soybeans crops]. RevBras Herbic. 2015;14(3):235-42. Portuguese. Available from: https://doi.org/10.7824/rbh.v14i3.383

Bressanin FN, Jayme Neto N, Martins JF, Martins JVF, Alves PLD$\mathrm{CA}$. [Control of Conyzo bonariensis resistant biotypes with glyphosate + chlorimuronethyl as a function of development stage]. Rev Bras Herbic. 2014;13(1):68-72. Portuguese. Available from: https://doi.org/10.7824/rbh.v13i1.208

Burke IC, Wilcut JW. Physiological basis for antagonism of clethodim by imazapic on goosegrass (Eleusine indica (L.) Gaertn.). 
Pestic Biochem Physiol. 2003;76(2):37-45. Available from: https://doi.org/10.1016/S0048-3575(03)00062-2

Burke IC, Wilcut JW, Porterfield D. CGA-362622 antagonizes annual grass control with clethodim. Weed Technol. 2002;16(4):749-54. Available from: https://doi.org/10.1614/0890-037X(2002)016[0749:CAAGCW]2.0.CO;2

Colby SR. Calculating synergistic and antagonistic responses of herbicides combinations. Weeds. 1967;15(1):20-2. Available from: https://doi.org/10.2307/4041058

Damalas CA. Herbicide tank mixtures: common interactions. Int J Agric Biol. 2004;6(1):209-12. Available from: https://www.fspublishers.org/lssue.php?no_download=published_papers/21906_..pdf\&issue_id=2562

Dayan FE, Zaccaro MLM. Chlorophyll fluorescence as a marker for herbicidemechanismsofaction.PesticBiochemPhysiol.2012;102(3):189-97. Available from: https://doi.org/10.1016/j.pestbp.2012.01.005

Frans R, Talbert R, Marx D, Crowley H. Experimental design and techniques for measuring and analyzing plant responses to weed control practices. In: Camper ND, editor. Southern weed science society: research methods in weed science. 3th ed. Champaign: Southern Weed Science Society; 1986. p. 29-45

Freire LR. [Rio de Janeiro state liming and fertilization manual]. Brasília, DF: Embrapa; 2013. Portuguese.

Gemelli A, Oliveira Jr RS, Constantin J, Braz GBP, Jumes TMC, Gheno EA et tal. [Strategies to control of sourgrass (Digitorio insularis) glyphosate resistant in the out-of-season corn crop]. Rev Bras Herbic. 2013;12(2):162-70. Portuguese. Available from: https://doi.org/10.7824/rbh.v12i2.201

Hao JH, Qiang S, Liu QQ, Cao F. Reproductive traits associated with invasiveness in Conyzo sumatrensis. J Syst Evol. 2009;47(3):245-54. Available from: https://doi.org/10.1111/j.1759-6831.2009.00019.x

Kukorelli G, Reisinger P, Pinke G. ACCase inhibitor herbicides: selectivity, weed resistance and fitness cost: a review. Int $J$ Pest Manag. 2013;59(3):165-73. Available from: https://doi.org/10.1080/09670874.2013.821212

Leal JFL, Souza AS, Ribeiro SRS, Oliveira GFPB, Araujo ALS, Borella J et al. 2,4-D and Haloxyfop-P-methyl interaction: sequential and interval applications to effectively control sourgrass (Digitorio insularis L.) and fleabane (Conyzo spp. L.). Agron J. 2020;112(2):1-11. Available from: https://doi.org/10.1002/agj2.20018

Machado AFL, Meira RMS, Ferreira LR, Ferreira FA, Santos LDT, Fialho CMT et al. [Anatomical characterization of the leaf, stem and rhizome of Digitorio insularis]. Planta Daninha. 2008;26(1):1-8. Portuguese. Available from: https://doi.org/10.1590/S0100-83582008000100001

Melo MSC, Rosa LE, Brunharo CACG, Nicolai M, Christoffoleti PJ. [Chemical control alternatives for sourgrass (Digitorio insularis) resistant to glyphosate]. Rev Bras Herbic. 2012;11(2):195-203. Portuguese. Available from: https://doi.org/10.7824/rbh.v11i2.145

Myers PF, Coble HD. Antagonism of graminicide activity on annual grass species by imazethapyr. Weed Technol. 1992;6(2):333-8. Available from: https://doi.org/10.1017/S0890037X00034825
Ottis BV, Mattice JD, Talbert RE. Determination of antagonism between cyhalofop-butyland otherrice(Oryzosativo) herbicidesinbarnyardgrass (Echinochloo crus-galli). J Agric Food Chem. 2005;53(10):4064-8. Available from: https://doi.org/10.1021/jf050006d

Rustom SY, Webster EP, Blouin DC, McKnight BM. Interactions between quizalofop-p-ethyl and acetolactate synthase-inhibiting herbicides in acetyl-coAcarboxylase inhibitor-resistantrice production. Weed Technol. 2018;32(3):297-303. Available from: https://doi.org/10.1017/wet.2018.15

Santos HG, Almeida JA, Oliveira JB, Lumbreras JF, Anjos LHC, Coelho MR et al. [Brazilian system of soil classification]. 3th ed. Rio de Janeiro: Embrapa Solos; 2013. Portuguese.

Sasaki Y, Nagano Y. Plant acetyl-CoA carboxylase: structure, biosynthesis, regulation, and gene manipulation for plant breeding. Biosci Biotech Bioch. 2004;68(6):1175-84. Available from: https://doi.org/10.1271/bbb.68.1175

Sousa CP, Farias ME, Bacarin MA. Chlorophyll o fluorescence in rice plants exposed of herbicides of group imidazolinone. Planta Daninha. 2014;32(1):141-50. Available from: https://doi.org/10.1590/S0100-83582014000100016

Strasser RJ, Tsimilli-Michael M, Srivastava A. Analysis of the chlorophyll a fluorescence transient. In: Papageorgiou GC, Govindjee S, editors. Chlorophyll a fluorescence: a signature of photosynthesis. Dordrecht: Springer; 2004. p 321-62

Thach LBA, Shapcott A, Schmid S, Critchley C. The OJIP fast fluorescence rise characterizes Groptophyllum species and their stress responses. Photosynth Res. 2007;94(2/3):423-36. Available from: https://doi.org/10.1007/s11120-007-9207-8

Tsimilli-Michael M, Strasser RJ. In vivo assessment of stress impact on plants' vitality: applications in detecting and evaluating the beneficial role of mycorrhization on host plants. In: Varma A, editor. Mycorrhiza. Berlin: Springer; 2008. p. 679-703.

Vieira Junior NS, Jakelaitis A, Cardoso IS, Rezende PN, Moraes NC, Araújo VT et al. [Association of post-emergence herbicides in corn]. Global Science Technol. 2015;8(1):1-8. Portuguese. Available from: https://doi.org/10.14688/1984-3801/gst.v8n1p1-8

Webster EP, Rustom SY, McKnight BM, Blouin DC, Teló GM. Quizalofop-p-ethyl mixed with synthetic auxin and ACCase-inhibiting herbicides for weed management in rice production. Int $J$ Agron. 2019;2019:1-7. Available from: https://doi.org/10.1155/2019/6137318

YusufMA, KumarD, RajwanshiR,StrasserRJ,GovindjeeTMM,SarinNB.Overexpression of $\gamma$-tocopherol methyl transferase gene in transgenic Brossico junceo plants alleviates abiotic stress: physiological and chlorophyll a fluorescence measurements. Biochim Biophys Acta. 2010;1797(8):1428-38. Available from: https://doi.org/10.1016/j.bbabio.2010.02.002

Zhang W, Webster EP, Blouin DC, Leon CT. Fenoxaprop interactions for barnyardgrass (Echinochloo crus-galli) control in rice. Weed Technol. 1995;19(2):293-7. Available from: https://doi.org/10.1614/WT-03-250R1

Zobiole LHS, Krenchinski FH, Albrecht AJP, Pereira G, Lucio FR, Rossi $C$ et al. [Perennial sourgrass control in full flowering growth stage]. Rev Bras Herbic. 2016;15(2):157-64. Portuguese. Available from: https://doi.org/10.7824/rbh.v15i2.474 